\title{
Trafficking in Women to Israel and Forced Prostitution
}

\author{
Israel Women's Network
}

\begin{abstract}
The following excerpts have been extracted from a report of the Israel Women's Network. The Israel Women's Network is a non partisan organization of women, representing a wide range of political opinions and religious outlooks, who seek to improve the status of women in Israel. The interviews and research for the report were done by Martina Vandenberg and Noga Applebaum, conducted between June 1997 and October 1997, throughout Israel. This report is the product of more than 50 interviews with Israeli law enforcement officials, government officials, academics, sex workers, crisis centre workers, Russian consular officials, and local experts.
\end{abstract}

\section{Precis}

Les extraits suivants proviennent d'un rapport rédigé par Réseau des Femmes d'Israël (Israel Women's Network). Le Réseau des Femmes d'Israël est une organisation non partisane de femmes, représentant un large éventail d'opinions politique et d'allégeances religieuses, et visant d l'amalioration du statut de la femme en Israel. La recherche et les entreoues pour ce rapport ont été menées en Israël entre juin et octobre 1997, par Martina Vandenberg et Noga Applebaum. Le rapport final est le résultat de plus de cinquante ent reoues avec des officiers de la force constabulaire israclienne, des officiels gouvernementaux, des universitaires, des travailleu-

Martina Vandenberg is currently studying lawa a Columbia University, in addition to working for Human Rights Watch. Before working in Israel with the Ismel Women's Network for six months in 1997, the author worked for the Global Suroival Network in the former Soviet Union.

Noga Applebrum is the Resource Centre Coordinator of the Israel Women's Network in Jerusalem, Isruel. ses «sexuelles», des travailleuses et travailleurs des centres de crise (crisis centres), des officiels du consulat de Russie, et des experts locaux israéliens.

\section{Introduction}

In the words of Judge Hanan Efrati, who has presided over trafficking cases in Israel, "We are talking about an industry and a sophisticated business operation." 1 This sophisticated operation has employees in both the former Soviet Union and Israel. Most of the women are recruited through want ads in newspapers. Theadvertisements promiselucrative opportunities to work abroad as waitresses, dancers, masseuses, nannies, or escorts. The women's trips and documents (often false) are arranged by local gangs in the country of origin. Partners of these gangs usually meet the women at the port of entry, immediately seize their passports, and brutally take complete control of their lives.

Some women come knowing that they will work as prostitutes. Others believe that they will work as waitresses or nannies and discover that they have been tricked only when they are dropped off at brothels or introduced to their first clients. There have even been a few documented cases of women abducted while visiting Israel and forced to work in prostitution.

Some observers argue that the majority of the women work voluntarily as prostitutes. But the debate over volition obscures the fact that behind these women is an enormous network of smugglers and mafia groups deliberately importing women into Israel and controlling their activity in the country. These groups almost invariably mistreat the women and violate their human rights. Many of the women are raped, beaten, robbed, bought and sold, and held in debt bondage. Trafficking into Israel is not simply a story of eco- nomic migration; it is a modern slave trade.

\section{The Extent of Trafiicking to Israel}

The Israeli government has publicly acknowledged the growth of trafficking. According to the official Israeli government report submitted at the Stockholm Conference in 1996,

... in the wake of the waves of immigration to Israel from Eastern Europe in recent years, the subject of illicit commerce in women, not necessarily minors, has taken its place on the police blotter. Young women are brought to Israel by criminal elements. They are ostensibly new immigrants and make use of forged identity papers. These young women are employed in "massage parlors" and brothels. There is a particular difficulty in identifying these young wom[e]n because of their forged papers ... The central units of the Israel Police (the units that deal with serious crime) carry out intelligence work with the objective of unveiling those involved in this trade and the places of their activity. These units conduct raids on massage parlors and brothels in order to put an end to their activities by putting those involved on trial or deporting them. ${ }^{2}$

There are no official numbers regarding the extent of prostitution in Israel. ${ }^{3}$ Esther Eilam, a sociologist and expert on prostitution, estimates that the total number of prostitutes in Israel is between 8,000 and $10,000 .{ }^{4}$ Conservative estimates put the number of imported women in the sex industry at one quarter of the total, 5 or more than 2,000 . The actual figure may be far higher. ProfessorMenachem Amir of Hebrew University, an expert on organized crime in Israel, estimates that 70 percent of the women working in prostitution in $\mathrm{Tel}$ Aviv are from Russia and other former Soviet republics. He believes that approximately 1,000 women are brought 
into the country illegally each year. ${ }^{6}$ Only a fraction are deported.

The Ministry of the Interior, which is responsible for deportations, did not supply researchers from the Israel Women's Network with nationwide deportation figures, despite promising to do so. But figures are available for some major cities. According to police, approximately 800 to 1,000 prostitutes work in Tel Aviv. ${ }^{7}$ In 1996, 360 foreign women were deported from Tel Aviv for working illegally in prostitution. ${ }^{8}$ In the northern city of Haifa, police are aware of 58 apartments used as small brothels, each with four or five prostitutes, and another six or seven large brothels, each employing 12 to 15 women. But in 1996, only 50 foreign women were arrested for working illegally as prostitutes in Haifa. In 1997, the statistics through August indicated an increase of 58 percent, with 79 foreign women arrested for prostitution in Haifa. 9

Dozens of women are held in the Neve-Tirza Prison or Abu-Kabir Detention Center for months because of bureaucratic delays in processing their deportations. So many in fact were arrested in 1995 that the prisons became overcrowded. Abu-Kabir, which has a capacity of 48women, hold some fifty, of whom thirty-nine were awaiting deportation. ${ }^{10}$ Another 50 women accused of prostitution were transferred to NeveTirza Prison due to lack of space. ${ }^{11}$ The average length of time in prison for these women is 50 days. ${ }^{12}$

The women are trafficked most frequently from Russia, Ukraine, the Baltic states, South Africa and the Dominican Republic. According to Israel's CEDAW report, more than 95 percent of the women deported from Israel for illegal prostitution are repatriated to the formerSoviet Union. 13

\section{The Money}

\section{Profits to Pimps}

The sums at stake are enormous. Estimates vary, but some experts believe that the prostitution mafia in Israel generates a turnover of $\$ 450$ million annually. ${ }^{14} \mathrm{~A}$ woman can earn from $\$ 50,000$ to $\$ 100,000$ a year for her pimp, accord-

\section{ing to Chid Thepector Mollicohen of the} Hayarkon precinct in Tel Aviv. ${ }^{15}$ Yitzak Tyler of the Haifa police explained:

If we are to talk about money, take for example a girl with 20 clients each day who pay 150 shekels [about \$40] each. The girls earn 3,000 shekels [about \$850] per day if they do not work very hard. There are. places here with 10 girls. Twenty five days? work with five girls is 375,000 shekels [over $\$ 100,000]$ ? that is what the pimp makes each month. He gives the girls 300 shekels [\$85] a day under the best of conditions. ${ }^{16}$

The Israeli importers often split the women's earnings with the brothel owners fifty-fifty. ${ }^{17}$ This can mean earnings for traffickers of over $\$ 60,000$ per year for each woman brought to Israel to work in prostitution.

When tax officials raided brothels in Tel Aviv, owners admitted holding earnings around 600,000 NIS [about $\$ 170,000]$. One brothel madam confessed to undeclared earnings exceeding 200,000 NIS [about $\$ 57,000$ ]..$^{18}$ The women seelittle of theseproceeds. In Tel Aviv, "The girls earn 170 shekels [about $\$ 50]$ per man. Seventy shekels goes to the brothel, and of the $100 \mathrm{NISleft}$ [\$30], 10 to 20 NIS [\$3-\$6] goes to the woman and the rest to the pimps."19

According to a newsletter published by a group of Israeli sex workers,

Some Russian girls that work in a certain massage parlor on Ben Yehuda Street in Tel Aviv complained to us about their conditions. The set price for a massage is 160 NIS [\$45], but the girls only get to take home 50 NIS [\$14]. Is this robbery or what? ${ }^{20}$

The author's life was threatened after this piece was published; the report clearly angered someone. ${ }^{21}$

Other sources indicate that the women keep even less of their earnings. According to accounts in Israel's Russian language press, the women "take about 150 NIS [\$40] from a client, but only 20-30NIS [\$6-\$9] are left for them by their 'bosses." 22 And the Tel Aviv Vice Squad has documented cases where women kept only 10 to 20 NIS [\$3-\$6] of the money per client. ${ }^{23}$
The women are gutwitly deported with nothing, according to sources at the Russian Consulate in Tel Aviv. The Russian Vice Consul, Igor Alekseev, interviews all women prior to deportation to confirm their identities and process new documents if none exist. $\mathrm{He}$ noted that the women who end up in prison do not have any money whatsoever. He believes that the pimps tip off the police to arrest women in order to avoid paying them at the end of their contract. The women depart penniless. ${ }^{24}$ In this way, the pimps can also avoid the $\$ 500+$ cóst of the return ticket to the FSU. If a woman does manage to smuggle any money out during the police brothel raid, the money is confiscated to pay for her return flighthome. ${ }^{25}$

While state deportation often adds to the pimps' profits, "sometimes the pimps want her to stay when she is a very successful prostitute," says Ministry of the Interior official Karmon. "The pimps are sometimes trying to keep the girl here and using all kinds of tricks. They sometimes bring a woman back with another identity." 26 In some cases women are sent back by their pimps as they have not "finished paying off their debt."27

\section{Mafia Involvement}

The mafia controls the sex industry throughout Israel. According to Israeli sources, the highest figures on the totem pole are immigrant Israeli bosses who make over $\$ 1,000$ per day. ${ }^{28}$ One sex worker interviewed reported that the bosses make closer to $\$ 3,000$ or $\$ 4,000$ per day and that the bosses were generally immigrants from the former Soviet Union. ${ }^{29}$ One step below are the parlour managers. Then come the bouncers and guards who earn as little as 4,000 NIS [about \$1100] per month. ${ }^{30}$

According to Ehrlich of the Tel Aviv ViceSquad, "This is a whole industryrecruiting them, bringing them [to Israel], and distributing them to all of the parlours." ${ }^{31}$ According to a sex worker who voluntarily moved to Israel to work for a company called "Escort Firm" and gavean interview to a Western joumalist, there are about rine or ten Russian prostitution rings operating in Israel.

Refuge, Vol. 17, No. 5 (November 1998) 
They have divided the territory and a truce now reigns among them. ${ }^{32}$ The truce is occasionally broken by brutal violence. In 1994, massage parlour owner Evgeny Dan was stabbed to death in Tel Aviv. A new immigrant from Georgia was arrested in connection with the death. ${ }^{33}$ Apparently, Dan had sought to recruit women from another parlour to work at his brothel, a major breach of mafia code. ${ }^{34}$

The mafia has found operation in Israel simplified by the mass migration of Jews from the former Soviet Union in the 1980s. According to one pimp interviewed in Moscow,

Two years ago, it was still difficult for us Russians to operate in Israel, because we didn't have a structure in place there. Now, though, we have plenty of Jewish immigrants working for us. Today there's hardly a brothel in Tel Aviv or Jerusalem where you can't find Russian girls. ${ }^{35}$

The mafia does have a very strong base in Israel. According to Karmon of the Ministry of the Interior, the Russian mafia has become very active over the past few years. Karmon told interviewers from the Israel Women's Network:

In 1994 many Russian mafia figures got citizenship and in February 1994 they had a conference at the Tel Aviv Hilton. Someone who was accepting bribes at a Ministry of the Interior regional office gavecitizenship to the mafia bosses. ${ }^{36}$

A protection racket has also grown up around the trafficking and prostitution business in Israel. In Haifa a criminal gang demanded protection money from a brothel owner. When the owner did not come up with the money, the gang demanded one of the brothel's call girls. A guard at the brothel was kidnapped and beaten severely by four members of the gang; the call girl was not released by the gang leader. Police arrested two suspects after setting up a sting operation. ${ }^{37}$

\section{Testimony by Trafficked Women}

Among police, there is a tendency to blame the women for not testifying and for the scarcity of convictions. In the words of Ehrlich of the Tel Aviv Vice
Squad, "If the women will not be witnesses, then there is no case." ${ }^{38}$ The Russian-speaking Israeli police officers have as one of their goals trying to get the woman to testify. "But the police have almost nothing to offer her to get her to testify."39 Sometimes the women do speak to the police, but are so afraid afterwards that they will not repeat the story. Tyler says that the testimony given in the police station is admissible, "but the police must prove that she is scared. She knows that groups will be waiting [when she gets home]." 40

Karmon of the Ministry of the Interior disputes the police position that the only evidence is the women's testimony:

I am arguing with the police all the time about this. There were only a few times when cases ever made it to court. Most of the time the women are just deported. The testimony must be made in the court-of course. But I tell the police that they can do their own investigation. They themselves can bring evidence. Police can document the men forging documents, they can tap their phones. $^{41}$

But the police claim that, despite the lack of criminal sanctions, the pimps are punished by the loss of their "property" - the prostitutes themselves. "Even if the girls don't talk, at least [the pimps] suffer some financial damages. The pimp paid $\$ 10,000$ for each girl. The pimp wants to kill himself-it is even worse than the punishmenthemightget in court." ${ }^{\prime 2}$ When the women are deported, the pimp must find another source of income, or so the story goes.

In the words of one critic,

... the police are used by the pimps for their own purposes ... the pimps call the police to visit their establishments when they are finished with the girls; the women are sent back from Israel as they came and the pimps are enriched twice. First, they need not pay the final instalment of the women's salaries. Second, the cost of returning the women to Russia is handled by the national budget. Meanwhile, the pimp is able to get a new shipment of fresh meat. ${ }^{43}$
This allegation was confirmed by an Israeli sex worker, "Gilda":

The Russian women are contracted to work for one year and they are supposed to get $\$ 1,000$ per month. In the eleventh month, the pimps make sure that the brothels are raided and the girls sent home. But the girls are forced to keep their money at the place [because of the inability to open bank accounts as a result of illegal status]. When they are busted, they can't take any of the money. The pimps simply take back all of the money that the women have hidden. ${ }^{44}$

Further confirmation comes from Karmon of the Ministry of the Interior:

Some of the consuls have said that the bosses give information to the police because they want the girls deported. The girls come and work and all their money is at this place of work. At some point they may want to work less, or they may want to go outside, they want to go home. The bosses don't want to pay them so they tell the police to raid a certain place. ${ }^{45}$

\section{Police Complicity}

Relations between the women from the FSU working illegally in Israel and the police are strained because of the perception that police fail to protect the women or punish the pimps. Police explain this as part of the legacy left from the Russian system. "In Russia there is distrustbetween the authorities and the people. The people are much more afraid of the criminals than of the police," says Yitzak Tyler, Commander of the Central Unit of the Haifa Police. ${ }^{46}$

Police corruption also plays a role in the relationship. Investigators recently discovered that one of the members of the Tel Aviv Vice Squad regularly warned brothel owners of raids in exchange for bribes and free sexual services. The officer's activities continued for ten months before he was suspended from the force. ${ }^{47}$

There is clearly a symbiotic relationshipbetween the police and pimps. The pimps and brothel owners are well known to police and criminal intelligence officers. Ehrlich sees his role as 
"supervision," that is, he tries to "supervise and check to see if there are any violent pimps." 48 The pimps themselves have no difficulty coming to police for assistance. In Haifa, when a guard was beaten and one of the sex workers of the brothel kidnapped, the brothel owner brought police in toset up a sting operation..$^{49}$ The police's central unit, under the command of Tyler, interviewed for this report, arrested the suspects after a "violent battle with police. ${ }^{\prime 50}$ And police in Haifa assisted when a brothel owner reported a kidnapping of two women employed at his establishment. The owner presented police with the women's passports. ${ }^{51}$

As described above, pimps provide useful intelligence to police on criminal activity in Israel. For that reason, they are very valuable sources, and police actively work to turn them into collaborators. According to Ehrlich,

The policy in raiding the brothels is not to arrest the pimps or the girls unless they break the rules and violate the guidelines of the state attorney. Everyone knows that prostitution exists and will always exist. 52

As a result, the raids are de facto immigration service sweeps. The police check documents and arrest only those women without papers or with false identification. The raids clear the brothels of illegal women immigrants from Russia and the former Soviet Union, but donot result in arrests of brothel owners or pimps.

Very few women seek out the police. In one unique case, a woman trafficked from one of the Baltic countries and forced to work as a prostitute escaped from the brothel where she worked. Given money by a pimp to go out and buy a sandwich, she instead took a taxi to the police station. Knowing that she would be deported, she simply wanted the abuse to stop. The police called the Tel Aviv Rape Crisis Center and one of the volunteers sheltered the woman for several months until she could identify and testify against the pimps. ${ }^{53}$ She has since relocated to a third country for security reasons.

\section{Arrest and Deportation}

According to police in Haifa, every woman deported costs the government over $\$ 500$. If the women have money, then they must pay for their own deportation. $^{54}$ The Ministry of the Interior pays for the flight home if the woman does nothave any money. In somecases, the Ministry of Labour can force theemployer to pay for the deportation. As Karmon says, "Most of the time it is better for the employer to pay to get rid of the girl so that she won't open her mouth. The tickets only cost $\$ 500 . " 155$

The process of deportation can take months. According to Ehrlich, "If the girl is caught with a fake I.D., then it is very easy to prove. But if the women havemarried or have borrowed identity papers, then the Ministry of Internal Affairs must do a long investigation." 56 The police are critical of the slow process of deportation. "There are not enough people at Internal Affairs. Two people in the whole country do this processing and it is too much work." 57 According to Karmon, the amount of time in jail depends on several factors:

Women sometimes spend months in jail when there is no proof of identity. Sometimes the documents have been thrown away ... If her identity is unknown, then there are no documents for her to leave. The consul must come and speak to the woman. No one wants the girl in their country if she is not really Ukrainian or Lithuanian. 58

\section{International Cooperation}

Consuls of various exporting countries do cooperate for the most part with Israeliauthorities. However, even thediplomats are frightened by the power of themafia. According to Karmon, "Some consuls are cooperating but even the consuls are afraid of the mafia. They have to go back to their countries and they have families in those countries. ${ }^{159}$

Consular officers are required to interview all of the women before deportation to check the validity of their documents. In many cases the Russian vice consul also calls friends and families for the women to try to find funding for their trips home. Often he calls the women's pimps (who do not identify themselves as such) to requestmoney to pay for return tickets to the Russian Federation. According to the vice consul, "It is better for [the pimps] to pay for the ticket and get rid of the woman. No person, no problem." 60

By and large, the consular officials feel helpless to deal with the problem. As Alekseev told investigators,

The information on trafficking of women here does not come to us ... We have the impression that the police are not very interested in this. They do not bother to find out how the women got here-they just want to deport them as quickly as possible. ${ }^{61}$

Embassy officials admit that they are not satisfied with the situation, "but the Consulate cannot do anything about it. We only meet with the girls who have already been arrested ... Russian law cannot reach rape and violence committed on Israeli territory." 62

\section{Conclusion}

The sex worker who co-founded the NGO "We Are Worthy" stated in an interview, "It maybe impossible to stop prostitution, but the rights of women must be protected. We donot believe in the slave trade." 63 The violations of the human rights of trafficked women in Israel are not prosecuted, discussed or even debated. The only remedy pursued by the Israeli government currently is quick deportation. The overall policy might bedubbed malicious neglect. The neglect allows the slave trade and the abuse to continue. And because of the Israeli government's failure to enforce its own laws, trafficking and pimping continue to be enormously profitable. As Karmon of the Ministry of the Interior has noted, "The main problem is one of money. There is so much money that people are losing their heads. The employers prefer people to be illegal be cause then the salaries are much lower. This is a magic circle and it is getting worse." 64 Esther Eillam, an Israeli sociologist, stated in an interview:

Unfortunately, the Israeli police are ignoring this. No one is interested in

Refuge, Vol.17, No.5 (November 1998) 
women prostitutes because the authorities seem to think some prostitutes are good for a healthy society. It is unbelievable that we should tolerate this trade in human beings in a modern, democratic society. 65

IWN received permission to interview women awaiting deportation at Neve Tirza women's prison shortly after this report was concluded. Due to the importance of these interviews, several are being added as an appendix.

\section{Appendix 1}

Interview with "Masha," age 19, November 13, 1997, Neve Tirza Prison

Iworked here as a prostitute. There is no work in Ukraine. I worked for three months and have already spent one month in jail. I am from a middle-sized town. When I was eighteen I worked as a prostitute in Yugoslavia and danced in a bar. Then I went home with some money. But I was in an accident and all the money disappeared on medical expenses. The money flew away. I hated living in Ukraine. I love to live abroad.

A friend helped me to gethere. Hedid my visa and he paid for my ticket. Icame here as a tourist. He did not demand any money from me- he is a friend from my town. When I got here I was not paid every month. We had an oral contract with the owner-he was supposed to pay us after our contract expired in one year. The girls are allowed to send money home, but the owner would not give us any of the money we earned. He took our documents away. We worked in a call-girl brothel-men would call and we would go to places to meet them. A guard went along if there was no phone number. 1 had 10 to 11 clients each day, but on my busiest day I had 24 clients. Some of them were Americans and some were foreigners from other countries. Some would pay for an hour. The clients paid me-it was over 150 shekels per client. The pimps earned a lot of money. They promised me $\$ 12,000$ after one year of work. I wanted to be a journalist.

Ilived with the other women together in anapartment. I won't say how many women work there. It is dangerous for me to talk about this. Why publish it anyway?

Working in prostitution is the hardest work in the world. We only do this because there is nothing in Ukraine. I want to move some place else and just live there. Inever thought I would work as a prostitute. I thought that it was very humiliating work. No one in Ukraine knows I do this except for one friend. I want to have my own salary and my own independence. Now I know the value of money. My mother cannot support me. I do not have anything to take home with me. The police gave me my stuff, but Idon't have any money.

Everyone knew that the apartment I worked in was full of girls. When we were raided I was in the shower. One of the girls called the police and told on us. She wanted to go home and so she turned us all in. They keep her separately because otherwise we would kill her.

The owner was a great guy and Idon't want to hurt him. Everything was great at the brothel we worked in-we went swimming, wehad days off. He kept all our money though. No one got paid at all for the first three months. I am not sure that I will ever be paid and he still has my passport. I think he will bring me a plane ticket though.

I will try to get the money back from him. It is my money. Iearned it. Butsomeone has to buy me a ticket home to Ukraine. I will go home when there is a flight. It would be better if he just broughtme the money. The consulgave me permission to leave.

Terrible things happened to my family because there was no money to pay for the apartment. I am afraid to goback to Ukraine-everyone wants money. Why is there no money in Ukraine?

\section{Interview with "Alina," November 20, 1997, Neve Tirza Prison}

The Russians here have a much worse relationship with the police and the guards than the Israeli women do. Our only violation is an administrative one-we overstayed our visas. We are normal, regular women.
We have no legal rights. A girlcomes to Israel and becomes a slave. There are so many tricks they play on you. So many Russian girls have been killed here. I know of four cases. The girls go to the pimp and ask for their money. They say, "I have worked, now pay me." The pimps refuse. There are so many cases like that ... I worked here one and a half years and I am going home with nothing.

Some of the girls go totally crazy. I worked in Tel Aviv for a pimp who was from Tashkent. I worked for two months and he paid me for my work. But he told menot tobring my money to work with me. He said that there might be a raid and that the police could take it. He said toleave it at home. He also threatened to fine me $\$ 5,000$ if I gave the money to anyone else to save for me.

One day I came home and $\$ 4,000$ had been stolen from my apartment. Ihad to start all over again. My pimp admitted that he had stolen the money. He knew that I wanted to take the money home and leave, so he stole my money. Then he fined me for complaining to him. He would fine us 1,000 shekels or 500 shekels for infractions. I told him I had a child to take care of. He said he didn't care at all for my child.I threatened to run away from the makhon. He demanded that I give him money to pay the fines. When I complained again he fined me 150 shekels per word. My complaint cost me 1,500 shekels in fines. He refused to give me any money back. He fined me for telling him the truth.

My pimp knew that we were here as tourists. He knew that we were in a strange country and that we had no rights. All the girls had to pay the fines. He did not beat anyone in front of me, but we all knew that there was a criminal case against him for assaulting and beating a woman and stealing her money. He was out working during the investigation and before the trial. The case kept being postponed and he continued working.

He also fined the Israeli girls-not just us. They came to him and split the money they earned with him 50-50. Before I worked for him I worked for another owner. 
That owner boughtme and then sold me to someone else for $\$ 10,000$. The owner told me I had to work off the $\$ 10,000$ that he paid for me. He said that it was my debt. He paid me 20 shekels for a massage and kept all of the money the clients paid.I had a huge debt to him. He closed all the doors on me.

They humiliated me and stole my money.

Iflewhere to Israel. A girlapproached me in the Ukraine and told me about working here. Someone I knew - an acquaintance-did all of my documents and bought my plane ticket. When I arrived, they picked me up and took me somewhere. There they showed me to a pimp as if I were a table or a piece of furniture. The man bought me.

I was working in the massage parlour when one day five men in masks came in with guns. They had pistols and they all spoke Russian. They pointed a gun at the cashier and tookall of the girls from the makhon. They put us in a car and took us to another owner and sold us to him. All my possessions were also left in that first massage parlour. I lost everything.

We had all almost just paid off the first pimp. But now we all had a new debt to pay. Wehad to eat, sleep, and do everything in the massage parlour. We were never allowed to go out.

When I was arrested the police did not interview me. They did ask if I wanted to do a criminal case, but then they immediately told me it would be better not to. The pimp would haveall of the protection-they told me that the pimp always wins. He has the money, he has a lawyer and he has all of the documents. And he is a citizen. Besides, they told me if Ibroughtcharges, I would have to stay in jail until the end of the case.

So the pimp wins and the girlsend up suffering physically and morally. We don't have any money for a lawyer and besides the pimps threaten that if you say anything they will kill your family when you get home.

My owner told me that if I talked, he knew my phonenumber athome and he said he would find me at home. He said that he would make my family suffer.
This is all such an emotional trauma for us. You have the mafia of pimps that controls you and then you are totally controlled by the prison and the state.

I thought about doing a case. But my pimp told me that he had money for a lawsuit. He said he had already set aside $\$ 20,000$ for his own defence. He also assured me that he would spend any amount of money tomakeproblems for me and my family. He said that even $\$ 5,000$ was not too much to pay to hurt me.

I have an eight year old child. I wanted to earn money to pay for all my child's expenses. Now in Ukraine you must pay for school, you must pay for their lunch at school, everything has to be paid for.

My third pimp tookallmy money and even borrowed money from me. I told him that I wanted to leave. He told me that I was offensive to him and that he was going to keep all of my moneyeven the money he had borrowed.

Ihad between 15 and 20 clients every day. I earned good money but the pimp stole it all through fines, threats, tricks. One day he threatened to throw me out into the street with nothing when he was mad at me. Another time he threatened my family and said that he could use all of his contacts back in Ukraine to hurt my family.

These pimps are sogreedy. They will sell their souls for nothing.

I went through hell in this country. It would notbe so horrible if Icould at least take something home. The most awful part is that I am leaving with nothing. This washell. It was a moral and physical hell. And no one will pay for it-no one is responsible. We are exported from the Ukraine because we are the cheapest product. We are an export.

\section{Notes}

1. Shyam Bhatia, "'Angels"' Find Hell in the Promised Land," The Observer, 1 December 1996, 15. Judge Efrati is a Magistrate Court judge in Tel Aviv.

2. State of Israel, "Statement of the Israeli Delegation to the World Congress against Commercial Sexual Exploitation of Children," presented Auguat 27-31, 1996, in Stockholm, Sweden, 4.
3. State of Istrael, Report to the Committee on the Elimination of All Forms of Discrimination Against Women, 1997, 62.

4. Interview with Esther Eilam, co-founder of "We Are Worthy," Tel Aviv, October 27 1997. Ellam cautions that these numbers are very difficult todetermine and include women who only work part-time in prostitution.

5. Tom Sawicki, "Slaves in a Strange Land," The Jerusalem Report, 24 August 1995.

6. Interview with ProfessorMenachem Amir, Hebrew University, Jerusalem, 23 June 1997.

7. Interview with Efraim Ehrlich, Commande of the Tel Aviv Vice Squad, Tel Aviv, 18 september 1997.

8. Ibid.

9. Interview with Yitzak Tyler, Commander of the Central Unit, Haifa, 15 September 1997.

10. Buki Naye, "There is NotEnough Spacefor the Prostitutes," Vesti, 21 December 1995.

11. Ibid.

12. The State of Israel, Report to the Committee to Eliminate All Forms of Discrimination Against Women, 1997, 64.

13. Ibid.

14. Shyam Bhatia, "'Angels' Find Hell in the Promised Land," The Observer, 1 December 1996, 15.

15. Tom Sawicki, "Slaves in a Strange Land," The Jerusalem Report, 24 August 1995, 10.

16. Interview with Yitzak Tyler, Commander of the Central Unit, Haifa, 15 September 1997.

17. Interview with Efraim Ehrlich, Commander of the Tel Aviv Vice Squad, Tel Aviv, September 18, 1997.

18. Raine Marcus, "Seven Tel Aviv Brothels Raided," The Jerusalem Post, 5 July 1996.

19. Interview with Efraim Ehrlich, Commander of the Tel Aviv Vice Squad, Tel Aviv, 18 September 1997.

20. "We Are Worthy," Newsletter, 23 October 1991, 24.

21. Interview with co-founder of "We Are Worthy," July 1997. "We Are Worthy" is an organization fighting for the rights of sex workers in Israel.

22. Evgenia Kravchuk, "Prostitution is not a Sin," Vremya, 10 July 1994.

23. Interview with Efraim Ehrlich, Commander of the Tel Aviv Vice Squad, Tel Aviv, 18 September 1997.

24. Interview with Igor Alekseev, Vice Consul, Russian Federation Embassy in Israel, 6 October 1997. 
25. Interview with Aleksandr Polipov, Consular Officer, Russian Federation Embassy in Israel, 6 October 1997.

26. Interview with BatyaKarmon, Ministry of the Interior, Jerusalem, 22 September 1997.

27. Interview with Aleksandr Polipov, Consu larOfficer, Russian Federation Embassy in Israel, 6 October 1997.

28. Gideon Maron, "Russian Mafia Re viewed," Vremya,9 December 1994. 29. Interview with co-founder of "We Are Worthy," Tel Aviv, 24 October 1997. 30. Gideon Maron, "Russian Mafia Re viewed," Vremya,9 December 1994. 31. Interview with Efraim Ehrlich, Com mander of the Tel Aviv Vice Squad, Tel Aviv, 18 September 1997.

32. Edward Shilling, "Russians Run Brisk Trade in 'Siberian Beauties:" reprinted in The Ethnic Newswatch, 7 July 1995.

33. Evgeniya Kravchik, "Murder in Tel Aviv: New Immigrant Evgeny Dan, 28:' Vesti, 11 December 1994.

34. Gideon Maron, "Russian Mafia Re viewed:' Vremya,9 December 1994. 35. Edward Shilling, "Russians Run Brisk Trade in 'Siberian Beauties:" reprinted in The Ethnic Newswatch, 7 July 1995.

36. Interview with Batya Karmon, Ministry of the Interior, Jerusalem, 22 September 1997.
37. "Alleged: A Guard at a Brothel Did Not Pay Protection Money and Was Kidnapped and Beaten Severely," Ma'ariv,28 September 1997.

18 September 1997.

39. Interview with Yitzak Tyler, Haifa, 15 Sep tember 1997. 40. Ibid. 41. Interview with

Batya Karmon, Ministry of

the Interior, Jerusalem, 22 September 1997

42. Interview with Efraim Ehrlich, Tel Aviv,

September 1997.

43. Dov Kontorer, "Look for the Pimp: Ma'ariv, 26 August 1997.

44. Interview with "Gilda:' Tel Aviv, 5 Octo ber 1997.

45. Interview with Batya Karmon, Ministry of the Interior, Jerusalem, 22 September 1997.

46. Interview with YitzakTyler, Haifa, 15Sep tember 1997.

47. "Suspicion that Detectives Involved in Warning Parlors of Raids:' Ha'aretz, 19

August 1997.

48. Interview with Efraim Ehrlich, Tel Aviv,

September 1997.

49. "Alleged: A Guard at a Call Girl Brothel Did not Pay Protection and was Kidnapped and Beaten Severely," Ma'ariv,28

\title{
Fr0111. Being Uprooted to Surviving: Resettlement of Vietnamese-Chinese UBoat People" in Montreal, 1980-1990
}

\section{By Lawrence Lam}

Toronto: York Lanes Press; ISBN 1-55014-296-8200 pages, indexed; \$18.95

\begin{abstract}
The saga of the "boat people" is a dramatic story, a story of one of the largest refugee movements in recent years. Canada played a significant role in the resettlement of these refugees in bringing them to Canada where they could start anew. From Being Uprooted to Surviving by Professor Lam, is based on ethnographic data of a sample of Vietnamese-Chinese accepted for resettlement in Montreal in 1979 and 1980, who were interviewed again in 1984-85 and in 1990-91, this book provides a longitudinal account of their experience of resettlement in Canada. This experience has been marked by successive stages of their struggle to overcome structural barriers and to negotiate a meaningful niche in Canada.

Contents: Preface, The Boat People Phenomenon, Resettlement-Issues and Perspectives, The Vietnamese-Chinese Refugees, Exodus and Transition, Resettlement Process-The First Three Years, Resettlement-Beyond the First Three Years, Conclusion.

\section{Available from:}

Centre for Refugee Studies

Fax: (416) 736-5837 • Email: refuge@yorku.ca
\end{abstract}

